\title{
The Role of Istanbul-Resident Iranians in the Development of Pan-Islamism Ideology (Case Study: Mirza Agha Khan Kermani \& Sheikh Ahamad Rouhi)
}

\author{
Ghaffar Abdollahi Matanaq ${ }^{1}$, Loqman Dehghan Niyeri ${ }^{1} \&$ Asghar Foroughi Abari ${ }^{1}$ \\ ${ }^{1}$ History Department, University of Isfahan, Isfahan, Iran \\ Correspondence: Ghaffar Abdollahi Matanaq, History Department, Litrature Faculty, University of Isfahan, \\ Isfahan, Iran. E-mail: ghaffarabdollahi@yahoo.com
}

Received: March 2, 2013 Accepted: April 2, 2013 Online Published: April 17, 2013

doi:10.5539/res.v5n2p128 URL: http://dx.doi.org/10.5539/res.v5n2p128

\begin{abstract}
In the $2^{\text {nd }}$ half of nineteenth century, when the Pan-Islamism ideology as the way out of Islamic world's straits was formed in the mind of some Islamic world's thinkers, some of Iranian thinkers joined the issue, as well. Mostly influenced by the ideologies particularly were Istanbul-resident Iranians intellectuals and thinkers who, oppressed by authoritarians of Iran, had taken refuge in Istanbul and started living there. Among them, Mirza Agha Khan Kermani and his inseparable fellow, Sheikh Ahmad Rouhi, had an interesting yet bitter adventure. Despite having non-religious ideological background, they were attracted toward Pan-Islamism, acted whole-heartedly and sacrificed themselves for it.

Using the remaining works by the two characters and other sources of that time, this study tried to recognize their roles in the movement of Pan-Islamism.
\end{abstract}

Keywords: Pan-Islamism, Iran, Ottoman Empire, Mirza Agha Khan Kermani, Sheikh Ahmad Rouhi

\section{Introduction}

The Nasseri Era is marked in terms of introducing new ideologies to Iranian community and the advent of new thinkers influenced by the West. In this period, nationalistic ideology and claiming for constitutionality made way into Iran and found proponents among the learned, occasionally merchants, and industrialists of the nation.

Pan-Islamism ideology was among the manifest ones in the last quarter of nineteenth century (early in fourteenth century AH). Although origin of the ideology was not in Iran, it infiltrated into the country finding enthusiastic advocates due to many close, especially cultural, relationships between Iran and Ottoman. Among them, the Istanbul resident Iranians were more influenced by the ideology, and some volunteered to make it flourish. Of the famous Iranians who joined the course playing a matchless role in its growth one may name Mirza Agha Khan Kermani and Sheikh Ahmad Rouhi. They were characters who had experienced a gross change in ideology in their short lifetime; once, they were students in old sciences and practiced traditional literature. Since they got familiar with works by individuals like Mirza Fath Ali Akhoundzadeh, they turned ardent archaists, for some time got into Babism turning an Azalist and even married the girls of Subh-i-Azal, and wrote about the Azali religion. As they entered Istanbul affected by its semi-European environment they acquainted themselves with new ideologies and literature; finally, as Saied Jamal Ad-Din Assadabadi (Afghani) at the invitation of Sultan Abdul-Hamid the $2^{\text {nd }}$ came to Istanbul and contended for Pan-Islamism, both turned his followers and coworkers.

Mirza Agha Khan Kermani and Sheikh Ahmad Rouhi acted wholeheartedly to develop Pan-Islamism, and as obvious from their works and letters, were hopeful that they would fulfill it, and deemed themselves dealing with too blessed and big a job. They were supported by the Sultan and other Ottoman authorities, and made themselves so pleased with these encouragements and supports that as always they occasionally acted very carelessly and even offended the majesty Nasser Ad-Din Shah. This was very conspicuous in the works and poetry by Mirza Agha Khan. Nonetheless, because at the time the Ottoman Empire faced many internal and external difficulties, it was likely it didn't agree to continue the promotion of Pan-Islamism without some considerations; therefore, as large governments like Russia increased their pressure aggravated by the Armenian 
uprising, the Ottoman government hesitated and stopped the Pan-Islamism movement in deed, leading its followers such as Mirza Agha Khan and Sheikh Ahmad Rouhi to fade into oblivion.

As Nasser Ad-Din Shah was assassinated, Mirza Agha Khan and Sheikh Ahmad Rouhi were arrested on charges of having hands at his murder, delivered to Iranian officers, and killed in Tabriz. In addition, the Sultan who no longer had the previous relationship with Saied Jamal Ad-Din and his relatives got terrified more than ever and was said to have got rid of Saied Jamal Ad-Din's threat.

\section{A Glance at the Biography of Mirza Agha Khan Kermani and Sheikh Ahmad Rouhi}

Mirza Agha Khan Kermani was born in 1853 at Mashiz village of Burdsir. His father, Abdul-Rahim Khan, was one of Bursir's khans. He studied at his hometown, Burdsir, and Kerman. For a period of time he was the tax collector of Burdsir, but since differences were found between him and Nasser al Dole Farmanfarma, Kerman Governor, and he was excommunicated due to his plots, he set off for Isfahan overnight and together with Sheikh Ahmad Rouhi served Zel-al- Sultan, the Isfahan Governor (Parizi, 1928: 680). But since the Kerman governor's complaints made their stay no longer possible, they left for Tehran and stayed there for some time. But since they found there insecure as well, they started off to Istanbul (Dolat-Abadi, 1967: 93-94). They travelled to Cyprus and visited the Subh-i-Azal and married his girls. So the two friends became brothers in law (1961: 471).

Sheikh Ahmad Rouhi was born in 1855 in Kerman. He acquired the Arabic sciences and jurisprudence alphabets and principles at the service of his father, Mullah Muhammad Ja'far Kermani. Furthermore, Sheikh Ahmad had a taste for poetry and adopted Rouhi as his pen name. For a period of time, he was the chaplain at Kerman mosques of Meidan Qala and Mirza Jabbar and was very skillful at preaching. He took Mirza Agha Khan as his paragon and put himself in his shoes (Nazim al-Islam, 1943:13). Referring to accompaniment and consultation of Sheikh Ahmad Rouhi with Mirza Agha Khan, Bastani Parizi gets surprised because they were very different in terms of family and belief background. This certainly is of surprise that Mullah Muhammad Ja'far Tah-e Bagh-Lellahi's son would accompany Mirza Agha Khan through such long ways that he gave up all his belongings and came to hold his beliefs ... (Parizi, 1928: 773). Mirza Agha Khan, in turn, treated Sheikh Ahmad with respect and called him his own minor master, as he had been studied by Mullah Ja'far for a period of time (Dolat Abadi, 1967: 94).

By teaching Persian, Arabic, and copying books, Mirza Agha Khan and Rouhi lived their lives In Istanbul. For a stretch of time, they worked in cooperation with Akhtar newspaper (Garni, 1956: 162). At that period, with Bab-e Ali resident Iranian officers getting them into trouble they experienced such a hard time that Mirza Agha Khan proposed his resolution in filing a complaint to the Ottoman Sultan: "I write to your Majesty to let you, especially, know that we Istanbul-resident Iranian nationals (traders, businessmen, etc.) have taken refuge in this city of welfare and capital of Caliphate so that we may at least be secure from oppressions and repercussions not be it so that even in this hub of Caliphate we are put to oppressions, indignity, disapproval, and mistreatment by anyone who wants to" (Kashmiri, 1929: 142). Moreover, Mirza Agha Khan tried to take an Ottoman subject, but Iranian Embassy thwarted his attempt (Sever, 2010: 142).

As Saied Jamal Ad-Din Assadabadi came to Istanbul at the invitation of the Ottoman Sultan, Mirza Agha Khan and Sheikh Ahmad Rouhi became his disciples. Their actions attracted the attention of Iranian Embassy. Iranian government, worried about Saied Jamal Ad-Din activities, regarded those close to him with suspicion and was sensitive to their activities. Iranian Embassy in Istanbul wrote a letter to Iranian Foreign Ministry dated December 1893 about the relationship of Mirza Agha Khan with Saied Jamal Ad-Din: "since Saied Jamal Ad-Din himself can't, due to the total ban by his Majesty, the Sultan, announce some issues in writing or words, he has employed Mirza Agha Khan and writes and receives the replies under his name, i.e. the writings are signed and sent by Mirza Agha Khan and replies are received under his very name; but the subjects and statements belong to Saied Jamal" (Khosroshahi, 1968: 248). Mirza Agha Khan and Rouhi wrote many letters to Iranian and non-Iranian scholars and thinkers to develop Pan-Islamism. They also recklessly criticized the Iranian government and Nasser Ad-Din Shah himself, and went on to the point that they didn't avoid remonstrating with the Iranian senior officials even the very Shah. Later on, this cost them dear. Mirza Agha Khan rebuked Shah audaciously and offensively in this manner:

"As the essence of polytheism ran in his blood,

his anger was stirred up with Pan-Islamism.

A doit is better than such a monarch

who has no creed, religion, nor faith. 
You terrified me in Ardebil,

by tying me to chains like is done to an elephant.

I don't fear being killed as I was born free

and with death"(Kermani, 1943: 51).

As problems raised between Saied Jamal Ad-Din and Sultan Abdul-Hamid the $2^{\text {nd }}$, the issue of Pan-Islamism was eliminated from the Sultan's list of priorities. Saied Jamal was kept under surveillance and his circle of friends and disciples dispersed and were no longer attended to by Ottoman officials. It was at this time when the Iranian ambassador thought of taking revenge on Mirza Agha Khan and Rouhi whom in his my mind were disloyal to the Shah and nation and even humiliated him. Incidentally, since it coincided with the uprising of Ottoman Armenians Mirza Agha Khan and Sheikh Ahmad were charged for having hands at the events. In addition to the ambassador's hostility toward Mirza Agha Khan and his friends, the commands transmitted to Tehran in connection with them were efficient. Accordingly, as some of the writings and letters by Mirza Agha Khan and Rouhi addressing the scholars of holy shrines reached Mirza Mahmoud Khan, the Iranian consul in Baghdad, he sent them to Nasser Ad-Din Shah should he know that Saied Jamal Ad-Din together with some Iranians and non-Iranians had attempted to surrender the Iranian Government to the Ottoman Sultan, apparently mentioned it under the name Pan-Islamism, and collected most of the scholars. After Nasser Ad-Din shah read the report he got so angry that he telegraphed the Iranian ambassador in Istanbul to politically charge all of those who were participating in the matter of Pan-Islamism along with Saied Jamal Ad-Din and Iranian nationals and expatriate them (Mudaresi Chahardehi, 1961: 291).

Apparently, Mirza Agha Khan had already felt the situation change. In a letter he wanted Mulkam Khan to prepare the ground for his travel to Europe and teaching the Oriental Alsunna in one of its cities. Understanding the possibility of transaction between Ottoman and Iran in regard with them, Mirza Agha Khan wrote, "I don't think the Ottoman government be so inhuman that it would surrender me to the Sultan. There is only one thing, i.e. the Armenians conditions make headway day after day, and the Ottoman government thinks that if it doesn't come to term with the Iranian government, he would receive support from the Armenians" (Garni, 1956: 179). In addition, Sheikh Ahmad Rouhi had the wish of travel to Europe and working there, and asked Edward Brown many times to provide a job for him. But he didn't get the help he had expected from Brown, and the letter writing between them came to a halt after a while (Brown, 1998: 170). Mirza Agha Khan also in a letter he had written on March the $10^{\text {th }} 1896$ to Edward Brown had requested for his help. He had asked Brown to save them from being terrorized by publishing their circumstance in European newspapers. He also had wanted him to publish his own works (Garni, 1956: 181). Interestingly, not Brown but Alaa al Molk, who got Mirza Agha Khan and his friends into trouble, went on to publish Mirza Agha Khan works and perhaps for clearance of conscience assumed the cost for the publication of his "The Letter of Ancient" (Nazim al Islam, 1943: 12). This work which is written, during the detention of Trebizond, on the pre-Islamic history of Iran is the only poetic work by Mirza Agha Khan. He wrote it with adoptions from Firdausi's Epic of Kings (Burdsiri, The Preface, 1958: 16).

Through Saied Jamal Ad-Din's measures and intermediation before the Sultan, it was agreed that they would return to Istanbul and be acquitted of charges. Sheikh Ahmad in a letter informed his mother about his immediate return to Istanbul and wrote of the respect and hospitability done to him and his two accompanying friends (Garni, 1956: 181).

But, using different ways, the Iranian ambassador prevented them from returning until Nasser-addin Shah was assassinated by Mirza Reza Kermani adding the interference therein to their previous charges. Seemingly, after Mirza Reza Kermani was discharged from the French hospital, he was welcome by Mirza Agha Khan, which added to pessimism of Iranian officials toward Mirza Agha Khan (ibid, 179). Put under pressure by the Iranian government, Mirza Agha Khan and Sheikh Ahmad Rouhi together with their friend, Mirza Hassan Khabir al Molk, were transferred to Tabriz. In Tabriz, at the presence of the prince all the three of them were beheaded as the chancellor, Amin al Sultan, had commanded (Nazim al Islam, 1943: 12).

\section{Mirza Agha Khan Kermani and the Pan-Islamism}

In 1892, when Saied Jamal Ad-Din Assadabadi (Afghani) came to Istanbul by the invitation of Sultan Abdul-Hamid the $2^{\text {nd }}$, years had passed since Mirza Agha Khan had been living in Istanbul (as of 1885). During those years, in addition to the completion of Turkish acquisition, he had got to know English and French and was influenced by new European ideologies; he also had written a number of works containing diverse subjects including Sheikhiye and Babish Beliefs, Speech Manners, and The Alexandrian Mirror. In the book The Alexandrian Mirror which is about the history of Ancient Iran, Mirza Agha Khan has, additionally, a chapter 
labeled "Expressing the specific advantages of history for each nation" and somehow goes on to discuss the philosophy of history (Kermani, 1969: 35).

Before Saied Jamal Ad-Din came to Istanbul, Mirza Agha Khan was familiar with his works and beliefs and kept a track of Saied's things and measures. Heard of Saied's travel to London, Mirza Agha Khan wrote in a letter: "a few nights before I came to London, I daydreamed that I had received a letter written in green from Imam Mahdi (pbuh) endorsed glorify Nizam al Dole on my behalf and tell him that he will be triumphant so vehemently ... a few days later, I read the news of the great Saied's arrival in which the green line referred to his lordship, this was the daydream come true. Take your triumph as granted (Kashmiri, 1929: 205)".

After Mirza Agha Khan got to know Saied Jamal Ad-Din, his ideology changed and was greatly influenced by Saied and his ideology. It seems that the role that the clergy played in the Tobacco Movement was effective in this change, and Mirza Agha Khan had become aware of their political power and religious instructions (Server, 2010: 110). However, Mirza Agha Khan was already sensitive to the conditions of Muslims and unhappy about their weakness. In his book "The Three Scripts" having a completely anti-Islamic paradigm he even expressed sorrow once again over the Muslim's inactivity and retard: "why it be so that one hundred millions Hindi Muslims wear yoke of servitude for five thousand English people; or, the majestic government of Istanbul, possessing the best parts of the world and ruling over one million Caliphate-worshiping pastors, execute the miniscule commands of Russia and obedient to the English ambassador (Kermani, 2000: 213).

As Saied Jamal Ad-Din established an assembly of the Istanbul-resident Iranians and non-Iranians called “Assembly of Pan-Islamism' to take measures for Pan-Islamism accomplishment, Mirza Agha Khan as well as his fellow, Sheikh Ahmad Rouhi, joined it. Mirza Agha Khan became a close friend of Saied and an industrious member of the circle to develop Pan-Islamism. Saied who was pursuing the goal of Pan-Islamism especially making Iran and Ottoman empire unified against European countries' threats did sweeping activities to encourage Muslims to join the Pan-Islamism, and took the duty of correspondence with scholar, Iranians, and Shiites over to Mirza Agha Khan and his friends. Mirza Agha Khan in a letter informed Malkam Khan of the actions they had done on the road to Pan-Islamism and of letters written to numerous persons. He also composed a poem he had written in the Trebizond prison:

"we wrote many deferential letters

to a couple of freewill men.

We sent the letters to Iraq

Where dissent was rising in the faith.

By help of the Creator

they were signed by all.

The letters were replied to affirmatively by Iranians and Iraqis,

suggesting they had resolved the dissent.

All sacrifice for the faith,

And pledge allegiance to the sultan of Islam" (Kermani, 1943: 50-53).

Yet, Mirza Agha Khan was dissatisfied with the speed tasks were being done. Criticizing the Iranians, he wrote, "Iranian People do not generally mind the importance, this is why they take matters easy, i.e. they accept and abandon them easily. They catch fire and go off soon like a withered leaf" (Kashmiri, 1929: 223). Furthermore, he complained about inaction of the friends and accused them of non-seriousness, "Agha Khan Mahalati's offspring have His Exellency Sheikh al Raees to stay in their home. He had sent a letter of great convenience; but oh God, this fire which has caught me won't be extinguished, as silence is suggestive of lethargy, in turn, of cowardice" (ibid, 223). Mirza Agha Khan, even, complained of Saied Jamal Ad-Din's lethargy: "After all those acts of contention and pretension, the ultimate Sheikh was made indifferent putting off the affairs as he, then, had the Egyptian Khedive and the Serbian king as his guests" (ibid, 223). Mirza Agha Khan wrote to Malkam Khan that he himself had also been influenced by Saied Jamal Ad-Din's inaction and no longer had the previous fervor giving the reason that "the concordance between discipleship and mastership is an already definite matter" (ibid, 227).

In addition to sending letters, Mirza Agha Khan had also been making use of other ways and facilities to propagate among Muslims. In a letter, he wrote of the potential Haj would have for Muslims' awakening. He wrote to Malkam that he had propagated and distributed handouts among hajis (ibid, 227). At that time, since 
hajis particularly those from Iran and Central Asia went to Mecca mostly via Istanbul, it was possible to propagate at their stay in Istanbul and Agha Khan used the opportunity.

The Pan-Islamism Mirza Agha Khan believed in was along with nationalism like its other versions. Essentially, the activists of the time didn't see any incompatibility between national and Islamic loyalties, and were nationalists and Pan-Islamists at the same time. This was not restricted to the Iranian activists and more or less the same was true about the Ottomans and Caucasians. Actually, Mirza Agha Khan's Pan-Islamism as well as that of other Istanbul-resident Iranians was a sort of Pre-Nationalism. Therefore, when Mirza Agha Khan favored the Pan-Islamism led by the Ottoman Sultan, he, in fact, intended to use the case as a political means against the Iranian shah's autarchy and the colonial powers of Europe (Server, 2010: 110). Probably, it was because of such considerations that Bastani Parizi referring to Mirza Agha Khan's Pan-Islamism wrote specifically allusively: "Mirza Agha Khan didn't abide by any faith, and the Subh-i-Azal's son in law as he was, he didn't stay with him; the Mirza Hussein Ali's disciples were hostile to him too and said, "he is hypocritical and secular and not steadfast" considering "the know-all, atheists, heretics, free thinkers, and cohabitants as wisest owning the brilliant sense", so, he wanted to create the Pan-Islamism with this background.(Parizi, 1928: 682). Unlike Bastani Parizi, Ahmad Kasravi deemed Mirza Agha Khan and his friends intimate in the task of Pan-Islamism: "These three men wrote letters to Iran, this and that under the name 'Pan-Islamism', set their wretched correspondents to fire and did anything to rescue them (Kasravi, 1968: 150). Niki Kadi has it that the participation of people such as Sheikh Ahmad Rouhi and Mirza Agha Khan Kermani in the movement of Pan-Islamism was in fact "caused by their enmity toward the Shah and Iranian government. They hoped the support for Sultan Abdul-Hamid would lead in the weakening of the Shah" (Kadi, 1967: 52).

When Mirza Agha Khan was serving in Trebizond prison, not sure of his future, he composed poems of Pan-Islamism, which can help us to perceive the whole movement:

"I wanted Muslims, to unite.

A political unification would originate

in Islam by the help of God.

Iran would turn Turkish and vice versa,

and there be no duality between the majestic Shahs.

Then, they would occupy the world by force,

taking the lives of their adversaries" (Kermani, 1943: 50-52).

Kermani, sorry for the way he and his friends were treated, wrote that some of the nasty and wicked ones wanted to annoy, for no good reason, those who made sacrifices for Muhammad's faith with the power of their writings which were stronger than the terminating cannons and "prepare the ground for identifying and killing them, woe to them and Evil is the home of oppressors" (Salmi, 1956: 66).

\section{Sheikh Ahmad Rouhi and Pan-Islamism}

Sheikh Ahmad Rouhi was one of Saied Jamal Ad-Din Assadabadi's friends and among his essential fellows to accomplish Pan-Islamism. Before Saied came to Istanbul, Sheikh Ahmad had taken an interest in him, which was clear in the context of letters he wrote to Brown. In a letter he wrote: "that man is one of the famous erudite men who have a future, has no flaw in nature except the slight scientific vanity, and wants only the best for the people" (Garni, 1956: 168). Nevertheless, he still didn't believe that all the problems of the Islamic world were caused by England and European countries and their colonial policy. Addressing all the Muslims who were seeking a change in situation and unhappy about underdevelopment of the Islamic world, he wrote: "if they want Islam to grow and be unified there nothing will come true unless they propagate sciences and want the best for humanity" (ibid, 168).moreover, he wasn't compatible with Saied's extremism and criticized him in this regard: "what blame the wretched English has instead of being peaceful and obedient to the Prophet's own family Muslims of your kind treated them as wickedly as you, being apparently and inherently a descendent of the Prophet inheriting his knowledge, were in Tehran, and the English who you deem atheist and irreligious have nowadays granted you asylum" (ibid, 169). After Saied Jamal Ad-Din came to Istanbul, Sheikh Ahmad was so influenced by his personality and ideology that he put aside his previous sensitivities and criticisms and came to wholly serve his beliefs. Sheikh Ahmad Rouhi along with his inseparable fellow, Mirza Agha Khan Kermani, led by Saied Jamal Ad-Din enthusiastically devoted themselves to the aims of Pan-Islamism making efforts wholeheartedly for it. So drowned in this ideology, Sheikh Ahmad Rouhi had chosen him the following rhyme:

"I'm a Pan-Islamist, 
my name came to be Ahmad Rouhi" (Parizi, 1928: 780).

At his stay in Istanbul, Rouhi wrote to his mother about his and his friends' activities: "My kind mother, to describe my conditions in detail is time-taking. In a nutshell, it is four months since I have been entangled with two kings of Islam, for the great service I together with a number of wise religious men have provided for them unifying Islamic nations". Then, he spoke of Nasser Ad-Din Shah's disagreement with the movement, pointing to the formation of Pan-Islamism Assembly by Saied Jamal Ad-Din Assadabadi with favors done to the upholders by the Ottoman Sultan, and considered it as the ignorance of Shah (Raeesnia, 1954: 567-568). Sheikh Ahmad Rouhi has also quoted a passage, in his letter, about the history of Pan-Islamism Assembly: "some time ago, i.e. two years ago, the Ottoman Lord asked that when you could invite Islamic nations to a political unification, should other Christian nations rise up against us, it'd be better all Muslims of world are united in order for us to help each other. And now, we, some wise men, wrote much to Baghdad scholars who gratefully accepted it and wrote on to the Ottoman Sultan. They were welcome by titles, gifts, and tributes. This led to our validity and reputation across the Ottoman government deciding to give boons and honors to us" (ibid, 709).

Rouhi was an idealist who didn't have enough information about ups and downs of politics; and, at the end, not only Sheikh Ahmad didn't reach the promised boons, but he also was victimized by the political transactions between Iran and Ottoman, and as Bastani Parizi has it: "The man who most of his zeal and effort was inside him more often followed Agha Khan, but there remained no track of him. Pan-Islamism was his belief... he had really been fooled with politics as he thought it possible to save the world that way; finally, he and his brother, Mirza Abu al-ghasim, lost their life for it" (Parizi, 1928: 782). Mirza Hussein Khan Danish Isfahani, an Istanbul-resident Iranian, wrote about the measure of Mirza Agha Khan, Sheikh Ahmad Rouhi, and their friend, Mirza Hassan Khan Khabir al Molk, with the same fate: "None of the three were familiar with the Western civil science and ceremonies or fully knew a European language; yet, they wanted to do the thing Voltaire, Jean-Jacques Rousseau, and Volney brought forcefully into effect through speech and writing in eighteenth century in France and Europe" (Jamali, 1930: 164-165).

\section{Conclusion}

Undoubtedly of the fates of Iranians who got to thinking of Pan-Islamism, those of Mirza Agha Khan Kermani and Sheikh Ahmad Rouhi were the most interesting yet bitterest. Once, the two were of the zealous nationalists and archaists, and another time were into Babism turning Azali and married two girls of Subh-i-Azal's. With such background, they turned fervent supporters of Pan-Islamism, and as with all their other tasks they continued extremism; finally they lost their life for it. Whether the two of them had been honest or joined Pan-Islamism only because of disagreement with the Iranian government is to be considered. That they had been idealists is doubtless, but one cannot accept that Mirza Agha Khan and Rouhi had been steadfast in Islam or any other faith let alone its unification. Therefore, it seems that they were liberals who had sought to weaken the dictatorial government of Nasser Ad-Din Shah by any means, and welcomed anyone who offered a version to stop him; and since they thought it right to develop Pan-Islamism this way, they made it welcoming.

Mirza Agha Khan Kermani and Sheikh Ahmad Rouhi couldn't see their ideals be realized in terms of Pan-Islamism; and while they were losing their life by the executioner, they probably understood the impracticability of the ideal. With both of them dead and Saied Jamal Ad-Din taken under surveillance, the Sultan Abdul-Hamid's movement of Pan-Islamism practically stagnated losing its early advancement. Although, years later, there still were twinkles of it, nobody took it serious, even the Jihad decree of the Ottoman Sultan didn't encourage Muslims to support Islamic Caliphate and do according to Pan-Islamism.

\section{References}

Adamiyat, F. (1978). Ideologies of Mirza Agha Khan Kermani. Tehran: Payam.

Bastani, P. (1968, July). Words about Mirza Agha Khan Kermani's Ideologies (No. 55 \& 56). Vahid.

Brown, E. (1998). Iranian Constitutional Revolution. Tehran: Kavir.

Burdsiri-Kermani, M. A. H. K., \& Haghdar, A. A. (Eds.) (2000). The Alexandrian Mirror. Tehran: Cheshmeh.

Burdsirir-Kermani, M. A. H. K., \& Abdullahiniya, A. (Eds.) (1999). The Ancient Letter. Kerman: Center for Kerman Studies.

Dolatabadi, Y., \& Barzabadi, F. M. (Ed.) (2008). The Life of Yahiya. Tehran: Firdaus.

Garni, J. (1997). Mirza Agha Khan Kermani, Sheikh Ahmad Rouhi, and Edward Brown (No. 94). Kelk.

Haghighat, A. R. (2002). The History of Iranian National Movements (Vol. 4). Tehran: Koumesh. 
Jamali, S. A., \& Khosroshahi, S. H. (Eds.) (1970). Documents about Saied Jamal Ad-Din Assad Abadi. Qom: Press Center for Islamic Propaganda Agency.

Kadi, N. (2008, July). Last Years in Istanbul (1892-1897) (No. 5). Hekmat and Ma'refat.

Kasravi, A. (2009). The History of Iranian Constitutionality. Tehran: Negah.

Kashmiri, M. (1970). Letters from Mirza Agha Khan Kermani. Historical Reviews (No. 1 \& 2).

Kermani, M. A. K., \& Choubine, B. (Eds.) (2000). The Three Scripts. Germany: Nima Wurlog.

Kermani, M. A. K., \& Mashkour, J. (Eds.) (1983). Seventy Two Nations. Tehran: Ataei Press Institution.

Kermani, N. I. (1984). The History of Iranians' Awakening. Tehran: Amir Kabir.

Khosroshahi, S. H. (2009). Documents about Saied Jamal Ad-Din Assadabadi in the Iranian Foreign Affairs Ministry. Tehran: Center for Foreign Affairs Publication.

Mudaresi, C. M. (2002). Saied Jamal Ad-Din and His Ideologies. Tehran: Amir Kabir.

Raeesniya, R. (1995). Iran and Ottoman on the Threshold of $20^{\text {st }}$ Century (Vol. 2). Tabriz: Sotoudeh.

Salmi, A. (1997). Epic of Ancient Times (Vol. 1, No. 1). Kerman: Humanities Faculty, University of Shahid Bahonar.

Sever, A. (2010). Jamal Ad-Din Afghani and Hamidian Islamism. Middle East Technical University. 